\title{
IMPROVE THE EFFICIENCY OF THE POWER TRANSMISSION SYSTEM USING THE GENETIC ALGORITHM TO DETERMINE THE OPTIMUM LOCATION AND FACTS DEVICES
}

\author{
Husam Hasan Mohammed ${ }^{1 *}$, Hiba Zuhair Abdul Kareem ${ }^{1}$, \\ AND WAFAA MOHAMMED RIDHA ${ }^{2}$ \\ ${ }^{I}$ Department of Electronic Technologies, \\ ${ }^{2}$ Department of Computer Systems, \\ Babylon Technical Institute, \\ Al-Furat Al-Awsat Technical University, 51015, Babylon, Iraq \\ *Corresponding author: husam171984@gmail.com \\ Husam10@atu.edu.iq
}

(Received: 23 ${ }^{\text {rd }}$ October 2019; Accepted: $4^{\text {th }}$ January 2020; Published on-line: $4^{\text {th }}$ July 2020)

\begin{abstract}
As the world's energy consumption increases, the expansion of the energy system becomes increasingly important. However, the creation of new transmission lines requires excessive costs and time if the same transmission capacity is to be added to the existing network. Today's electrical networks are faced with high risks of voltage instability and real power losses. This development tends to occur due to the lack of reactive control power (RPL) in heavily stressed operating conditions caused by increased demand for loads and the rapid development of power systems worldwide. This paper has adopted the setting of FACTS (flexible AC transmission system) devices as additional control parameters for reducing transmission losses in power system static types of two FACTS devices consisting of SVC (static VAR compensators) while the TCSC (thermistor controlled series compensator) is included in the issue formulation. During this paper, the proposed algorithm was to determine the optimal placement of power network devices by genetic algorithm to manage reactive power, reduce losses, increase the transmission capacity and power lines, and help simulate the IEEE 24 bus control system and also the position of FACTS devices.
\end{abstract}

ABSTRAK: Apabila penggunaan tenaga dunia semakin meningkat, penambahan sistem tenaga sangat penting. Walau bagaimanapun, penciptaan talian penghantaran terkini memerlukan kos yang berlebihan dan had masa jika kapasiti penghantaran yang sama digunakan dengan lebih tinggi. Dalam rangkaian elektrik hari ini, unit ini berhadapan dengan risiko ketidakstabilan voltan dan putus bekalan tenaga. Penambahan sistem tenaga ini cenderung berlaku disebabkan kekurangan kuasa kawalan reaktif (RPL) dalam keadaan beban operasi yang besar disebabkan oleh peningkatan beban permintaan dan perkembangan pesat sistem kuasa di seluruh dunia. Kertas ini telah mengguna pakai peranti FACTS (sistem penghantaran AC fleksibel) sebagai parameter kawalan tambahan bagi mengurangkan kehilangan penghantaran dalam sistem kuasa statik dua peranti FACTS yang terdiri daripada SVC (pemampas VAR statik) manakala TCSC (pemampas siri termistor kawalan) adalah termasuk dalam perumusan isu. Dalam kertas kerja ini, algoritma yang dicadangkan adalah penempatan optimum peranti rangkaian kuasa oleh algoritma genetik bagi mengurus kuasa reaktif juga mengurangkan kerugian dan meningkatkan kapasiti penghantaran dan kabel elektrik dan membantu menyerupai 
sistem kawalan bas IEEE 24 dan juga kedudukan peranti FACTS di mana ia terbukti berkesan.

KEYWORDS: FACTS devices; genetic algorithms; SVC; TCSC; optimal location

\section{INTRODUCTION}

Reducing oil and gas reservoirs and increasing energy consumption worldwide have encouraged researchers to consider optimizing generation and energy transmission in power grids to increase efficiency and improve plant utilization, reduce losses, and preserve the environment. Studies show that FACTS technology has increased transmission capacity, reduced losses of power and load density, and improved reliability, performance and control by maintaining the voltage profile and affecting transmission parameters [1]. In recent years, reactive power control and loss reduction in power systems are performed through optimal location of FACTS devices using smart algorithms. Genetic Algorithm (GA) is one of the computer science exploration techniques used to find approximate solutions for optimization of exploration problems [2]. FACTS devices were first presented by Electric Power Research Institute (EPRI) in 1990 in the USA [3]. These devices not only increase system loadability but also control power to a great extent. They are also able to improve system stability due to their high speed [4].

\section{POWER LOSSES}

For solving this problem, continuous variables such as generator bus voltage, and discrete variables such as parallel switching size and FACTS series devices are used, and the objective function is to reduce the power network loss index. The real power loss $\left(P_{\text {Loss }}\right)$ in transmission networks is calculated as the following [5]:

$$
P_{\text {Loss }}=\sum_{K=1}^{N_{L}} G_{K}\left(V_{i}^{2}+V_{j}^{2}-2 V_{i} V_{j} \cos \theta_{i j}\right)
$$

Where, $N_{L}$ is the number of the branches of the power system, $P_{\text {Loss }}$ is the loss of a branch, $G_{K}$ is the conductance of the branch K. $V_{i}$ and $V_{j}$ voltages at the beginning and end of the branch. $\theta_{i j}$ is the power angle difference between $i j$ bus. The constraints that are considered for this problem include nonlinear equality of power flow equations and the linear inequality of various parameters [6] as the following:

$$
\begin{gathered}
P_{G i}=P_{D i}+V_{i} \sum_{N=1}^{N_{B}} V_{j}\left(G_{i j} \cos \theta_{i j}+B_{i j} \sin \theta_{i j}\right) \\
Q_{G i}=Q_{D i}+V_{i} \sum_{N=1}^{N_{B}} V_{j}\left(G_{i j} \cos \theta_{i j}+B_{i j} \sin \theta_{i j}\right)
\end{gathered}
$$

The equation (2) and (3) follow the following constraints[6]

$$
\begin{aligned}
V_{i}^{\min } \leq V_{i} \leq V_{i}^{\max } \quad i \in N_{B} \\
T_{i}^{\text {min }} \leq T_{i} \leq T_{i}^{\max } \quad i \in N_{j} \\
Q_{G_{i}}^{\min } \leq Q_{G_{i}} \leq Q_{G_{i}}^{\max } \quad i \in N_{P V} \\
Q_{C_{i}}^{\min } \leq Q_{C_{i}} \leq Q_{C_{i}}^{\max }
\end{aligned}
$$$$
i \in N_{C}
$$ 
Where $P_{G i}$ and $Q_{G i}$ are active and reactive powers of bus. $P_{D i}$ and $Q_{D i}$ are active and reactive consumption powers of bus $i . G_{i j}$ and $B_{i j}$ are real and imaginary parts of component ij of admittance matrix of the network. $\boldsymbol{N}_{\boldsymbol{B}}$ is the number of buses of the network. $\boldsymbol{N}_{\boldsymbol{P V}}$ is the set of buses of the generator. Indices min and max are minimum and maximum value of each parameter. $\boldsymbol{N}_{\boldsymbol{C}}$ is the number of shunt VAR compensation $\boldsymbol{Q}_{\boldsymbol{C}}$.

\section{THE MODEL OF SVC}

The static var compensator (SVC) parallel compensator is a static capacitance/inductance with susceptance of BSVC shown in Fig. 1, which is, modelled as a variable susceptance in parallel with BSVC at bus $i$. The reactive power injected to bus of SVC is described as follows[7]:

$$
Q_{s v c}=B_{s v c} \cdot V^{2}
$$

where $\mathrm{V}$ is the amplitude of the voltage for the bus that SVC is connected to. The main task of SVC is to regulate voltage of the bus, which is done by controlling reactive power injection at that point. As shown in Fig. 1, the equivalent circuit of SVC can be represented as a variable susceptance [8].

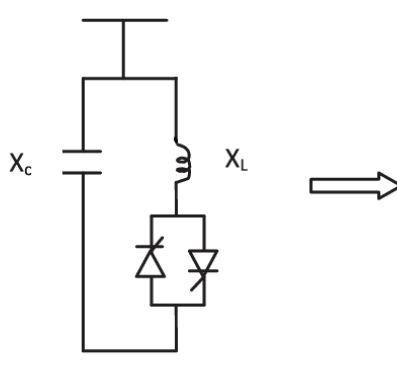

(a)

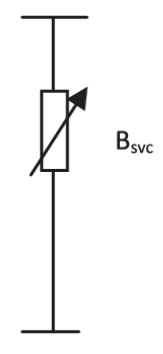

(b)

Fig. 1: The static VAR compensator (a) basic structure (b) model.

The new admittance of the system after installing SVC in the i bus can be expressed by the following matrix:

$$
Y_{\text {bus }}^{\text {SVC }}=Y_{\text {bus }}+\left[\begin{array}{ccccccc}
0 & 0 & 0 & \ldots & 0 & 0 & 0 \\
0 & Y_{\text {shunt }} & 0 & \ldots & 0 & 0 & 0 \\
0 & 0 & 0 & \cdots & 0 & 0 & 0 \\
\cdots & \cdots & \cdots & \cdots & 0 & \cdots & 0 \\
0 & 0 & 0 & \cdots & 0 & 0 & 0 \\
0 & 0 & 0 & \cdots & 0 & 0 & 0 \\
0 & 0 & 0 & \cdots & 0 & 0 & 0
\end{array}\right]
$$

where, $Y_{b u s}$ is the admittance of the system without SVC.

For constant active power and $\mathrm{V}_{\text {rms }}$ source voltage, the required capacitive reactive power varies before and after the capacitive compensator is installed:

$$
V A R(\text { capacitive })=V A R(\text { required })-V A R
$$

As the value of $\mathrm{B}_{\text {cap }}$ capacitive susceptance is given by the following equation:

$$
B_{\text {cap }}=\frac{V A R(\text { required })-V A R(\text { Uncompensated })}{V_{r m s}^{2}} \cdot S
$$

And capacitance required in farad is calculated as follows: [2] 


$$
C(\text { Farad })=\frac{B_{\text {cap }}}{(2 \pi f)}
$$

\section{THE MODEL OF THYRISTOR CONTROLLED SERIES COMPENSATOR TCSC}

The TCSC is a capacitive reactance compensator that consists of a series capacitor bank shunted by a thyristor-controlled reactor. The basic conceptual TCSC module comprises a series capacitor, $\mathrm{C}$, in parallel with a thyristor controlled reactor Fig. 2A [9]. The TCSC compensator is a static reactor capacitance with the impedance of jxc with susceptance of BSVC shown in Fig. 2B [9]. The thyristor is modelled with a nonlinear resistance that is controlled by firing angle [10]. Current of inductance and voltage of capacitance are selected as two variables in state space.

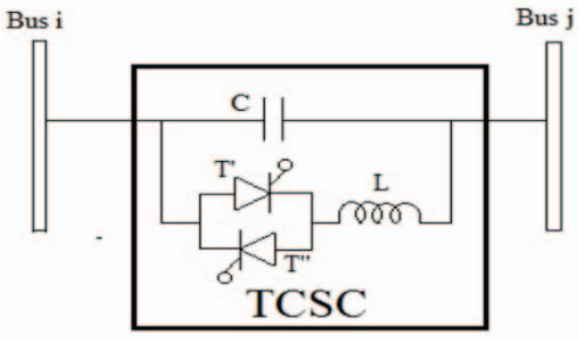

a

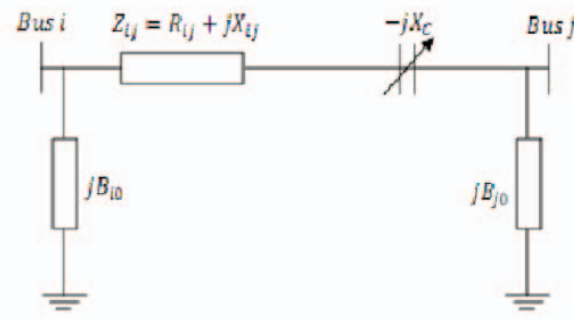

$\underline{\mathrm{b}}$

Fig. 2: Thyristor controlled series compensator presentation:

(a) basic structure, (b) model.

$\mathrm{X}_{\mathrm{ij}}$ is the line reactance, $\mathrm{R}_{\mathrm{ij}}$ is the line resistance, $j B_{j o}, j B_{i o}$ are load susceptance of half of the line at bus $i$ and bus $j$ of the line. The difference between the line susceptance before and after TCSC installation is as follows:

$$
\begin{aligned}
& \Delta y_{i j}=y_{i j \text { old }}-y_{i j \text { new }}=\left(g_{i j}+j b_{i g}\right)_{o l d}-\left(g_{i j}+j b_{i j}\right)_{n e w} \\
& g_{i j \text { old }}=\frac{r_{i j}}{\sqrt{r_{i j}^{2}+x_{i j}^{2}}}, \quad b_{i j \text { old }}=-\frac{x_{i j}}{\sqrt{r_{i j}^{2}+x_{i j}^{2}}} \\
& g_{i j \text { new }}=\frac{r_{i j}}{\sqrt{r_{i j}^{2}+\left(x_{i j}+x_{c}\right)^{2}}}, \quad b_{i j \text { new }}=-\frac{x_{i j}+x_{c}}{\sqrt{r_{i j}^{2}+\left(x_{i j}+x_{c}\right)^{2}}}
\end{aligned}
$$

The new admittance of the system after connecting TCSC between the $i$ and $j$ bus can be expresseing by the following matrix:

$$
Y_{b u s}^{T C S C}=Y_{b u s}+\left[\begin{array}{ccccccc}
0 & 0 & 0 & \cdots & 0 & 0 & 0 \\
0 & \Delta_{y_{i j}} & 0 & \cdots & 0 & -\Delta_{y_{i j}} & 0 \\
0 & 0 & 0 & \cdots & 0 & 0 & 0 \\
\cdots & \cdots & \cdots & \cdots & 0 & \cdots & 0 \\
0 & 0 & 0 & \cdots & 0 & 0 & 0 \\
0 & -\Delta_{y_{i j}} & 0 & \cdots & 0 & \Delta_{y_{i j}} & 0 \\
0 & 0 & 0 & & 0 & 0 & 0
\end{array}\right]
$$


where, $Y_{\text {bus }}$ is The admittance of the system without TCSC. Eq. (17) shows new reactance of the line after installing TCSC.

$$
x_{\text {new }}=x_{\text {old }}-n \cdot x_{\text {old }}
$$

where, $x_{\text {old }}$ is the reactance of the line without TCSC and the $n$ is in the range of

$$
0.25 x \text { line } \leq n \leq 0.75 x \text { line }
$$

\section{THE PROPOSED METHOD}

One of the most important advantages of intelligent methods is that there is no specific space to find the best solution. Among the intelligent methods, we can mention Simulated Annealing (SA) [11], Tabu Search method (TS) [12] and particle swarm optimization technique [13]. We decided in this paper to use the method of GA. GA uses one of the natural Darwin's selection principles for finding an optimal formula to predict or match patterns [14]. In summary, it is said that GA is a programming technique that employs genetic evolution to solve problems. The summary of a genetic algorithm is as follows:

Beginning: Create $\mathrm{n}$ chromosomal population randomly (appropriate solutions to the problem).

Valuation: Assess the fitness $\mathrm{f}(\mathrm{x})$ of each chromosome $\mathrm{X}$ in the population.

$>$ New population: Create a new population. Repeat steps below to complete the new crowd.

- Choice: Choose two chromosomes (parents) according to their fitness from the crowd. The higher the chances, the better the chances of being chosen.

$>$ Combination: Combine the possibility of combining parents (Probability Crossover) to form new children (Offspring).

Mutations: A mutation occurs with the probability of children mutation in each locas (position on the chromosome).

$>$ Accepting: Include new children in the new population.

Replacement: Use the new population created for the algorithm process

The main objective of this work is to find the best place for the FACTS devices, their types, and their values. Special coding was developed to achieve parameters (location, type, value). The first string represents the location of the FACTS devices, where it contains the numbers of lines. As for the second string, it is to determine the type of FACTS devices added. The value of the added device is determined by the last string, which is between 0 and 1 where 0 represents the minimum, and 1 represents the maximum. The real value of the FACTS device $v_{\text {realf }}$ can be calculated using the following equation:

$$
v_{\text {realF }}=v_{\min F}+\left(v_{\max F}-v_{\min F}\right) v_{F}
$$

where $v_{\max }$ and $v_{\min F}$ are respectively the maximum and the minimum setting value of the FACTS device, and $v_{F}$ is the normal value. The initial population of the system depends on the following parameters:

- $n_{F}$ The number of FACTS devices that are selected as optimal

- Types of FACTS devices that will be determined

- $n_{v}$ Represents the number of special settings for each device

- $n_{i}$ Represents the number of individuals of the population. 
At each of the three stages is created:

- In the first string, a set of numbers of branches of the network are randomly placed.

- The second step is to draw random numbers indicating the types of devices and placed in the second string

- In the third step, the values of the devices are chosen randomly within the possible limits.

The objective function will be calculated for each individual population previously configured and the objective function in this paper is the effect of the FACTS devices in the power system. A slice will be allocated in the roulette wheel for each individual population. The size of the slide is proportional to each individual and the appropriate individual will occupy a larger slice, as in Fig. 3. The wheel will be rotating many times and after the wheel stops, the individual to which it refers will be selected.

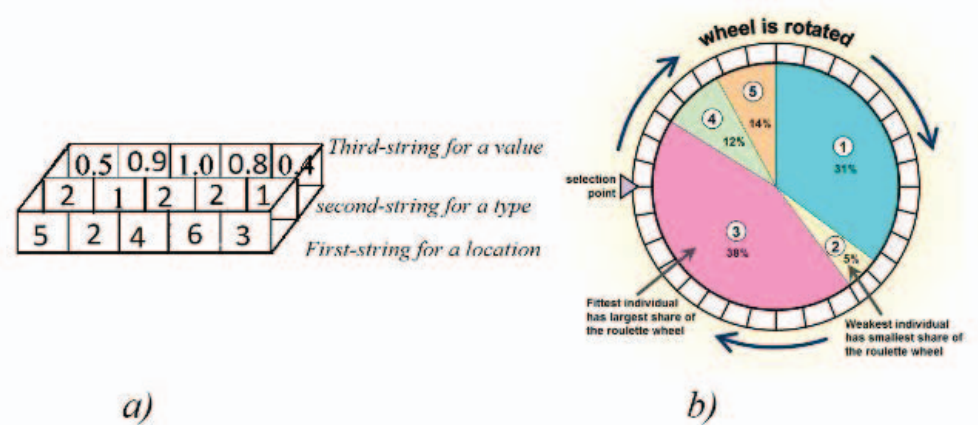

Fig. 3: Arrangement of 2 FACTS devices (a) Individual, (b) Roulette wheel to select individuals.

\section{DETERMINE THE LOCATION AND VALUE OF THE FACTS DEVICES WITH THE GENETIC ALGORITHM (GA)}

$>$ First, initial conditions are considered for system loads. This initial condition might be based on the basic load of the system.

$>$ For generator buses (except reference bus), an initial active power proportionate to the load is determined.

The power flow program is executed.

- The power flow program might diverge due to excess increase in load condition of the system. In this case, the previous load condition is considered as the maximum load condition and step 6 is performed.

$>$ GA and the employed devices are used to define the objective function (reducing losses).

Real genetic program is executed.

$>$ The algorithm represents optimal size and location of TCSC and SVC and the considered index through iterative and random selection.

The program is finished.

\section{SIMULATION AND RESULTS}

In this section, location of SVC and TCSC in a standard IEEE 24-bus system is investigated using GA and the results are presented. Performance of the system is first 
investigated in the absence of FACTS devices and then in the presence of these devices. Figure 4 shows the single-line diagram of the IEEE 24-bus system. This network has 38 transmission lines which are assumed to have no problems in terms of thermal capacity [15]. In this network, there are 10 generator buses where bus 23 is considered as the Slack bus, 10 PV bus and 13 PQ buses. In this network, it is assumed that initial load of the system is $2700 \mathrm{MW}$ and 549.474 MVAR. During execution of the program, as system load increases, this ratio is preserved.

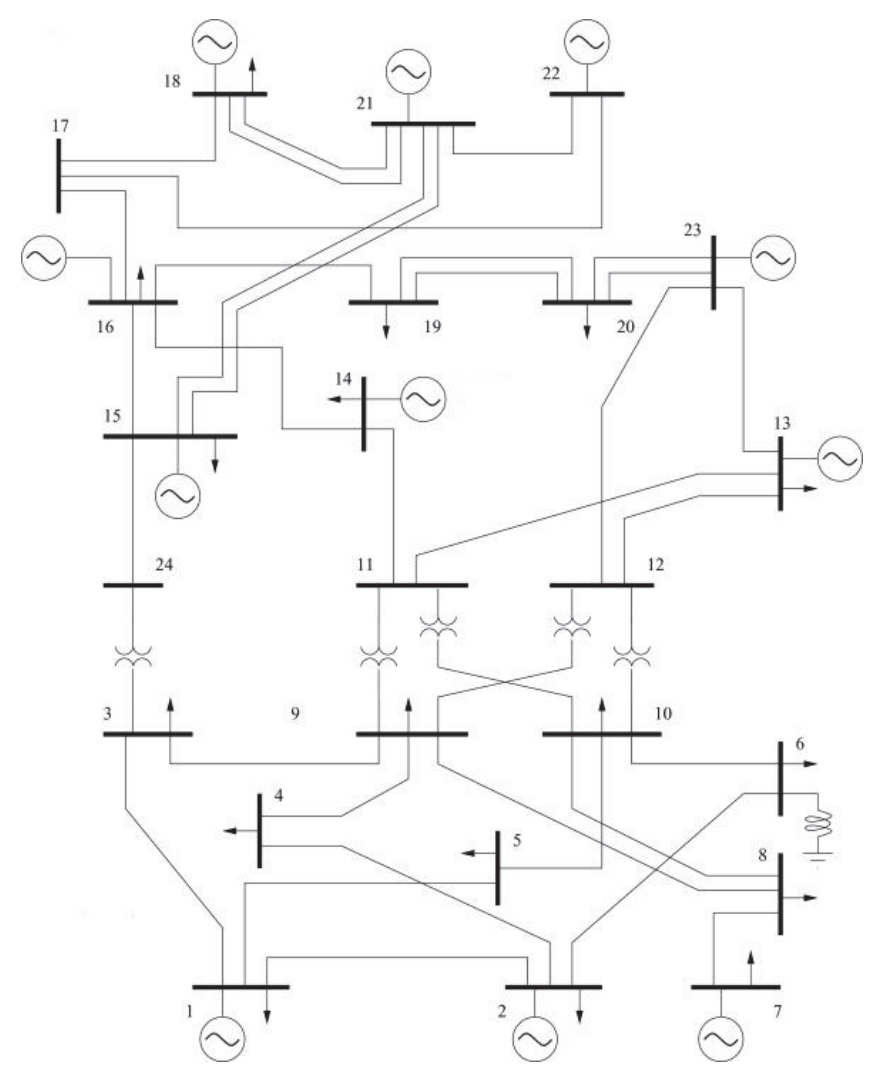

Fig. 4: Single-line diagram of the IEEE 24-bus system.

\subsection{Losses Index in IEEE 24-Bus System Without Installing Facts Devices}

Loss index in 24-bus system without installing FACTS devices is 225.68 MVA using GA.

\subsection{Losses Index by Installing SVC At IEEE 24- Bus}

As it is known, when SVC is installed in this system, considering all buses of the system, there would be 24 possible locations for SVC. Encoding region of the location is considered as 24 integers from 1 to 24 . After using real GA, it is seen that considering bus 10 as the optimal bus with a capacity of 225.69 MVAR, loss index is reduced to 218.786 MVA.

\subsection{Losses Index by Installing TCSC in the IEEE 24-bus System}

As mentioned before, there are various methods for controlling TCSC. Among these methods, controlling power flowing through line, controlling phase angle at the ends of the line, and constant compensation of transmission line reactance can be mentioned. In this study, constant compensation of transmission line is used to establish steady state conditions. If all lines of this system are considered, there would be 38 possible locations 
for TCSC. Encoding region would be 38 integers from 1 to 38. Compensation percentage using TCSC is $60 \%$. After using real GA, it is seen that considering line 27 which is between buses 15 and 24 as the optimal location of TCSC with magnitude of 0.581 , loss index is reduced to 208.865 MVA.

\subsection{Losses Index by Installing a Combination Of SVC and TCSC in the IEEE 24-Bus System}

In this case, installing a combination of TCSC and SVC is studied and its results are compared with each other. After using real GA, it is seen that considering line 27, which is located between buses 15 and 24, as the optimal location for installing TCSC with magnitude of 0.581 and bus 10 as the best location for installing SVC with capacity of 225.69MVAR, loss index is reduced to 201.765MVA. The voltage profile curve for IEEE 24-bus system is shown in Fig. 5 to Fig. 7.

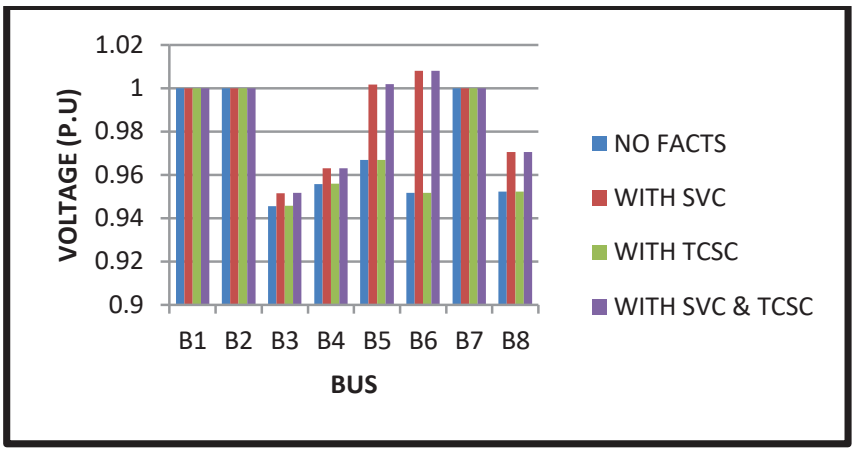

Fig. 5: Voltage profile of buses (1-8) for the IEEE 24-bus system.

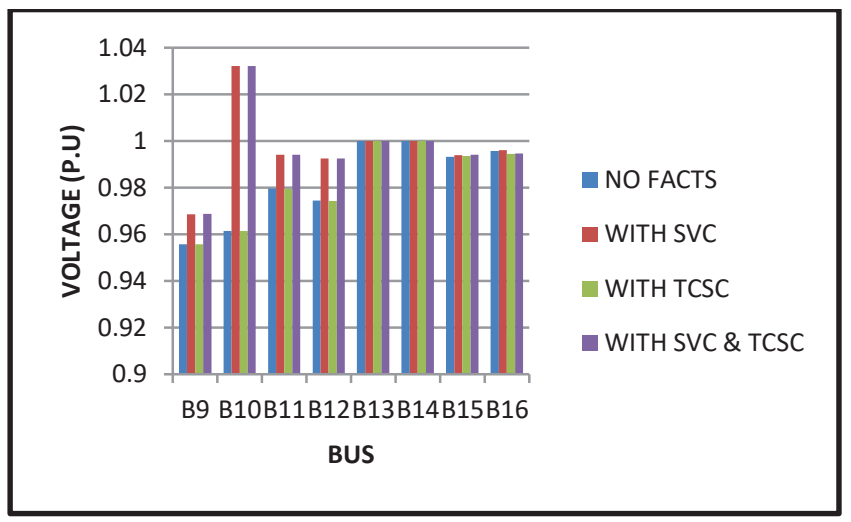

Fig. 6: Voltage profile of buses (9-16) for the IEEE 24-bus system.

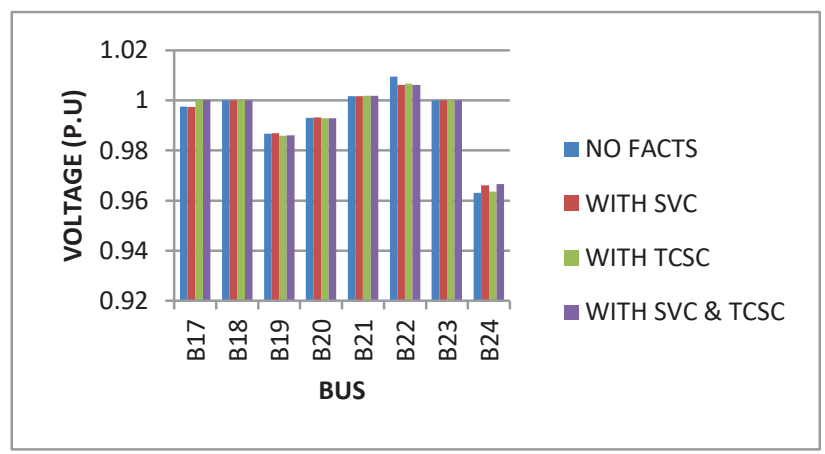

Fig. 7: Voltage profile of buses (17-24) for the IEEE 24-bus system. 
When referring to Fig.5-7, we notice a significant improvement in the voltage profile of buses after installing a combination of SVC and TCSC. For example, the bus voltage number 5 was 0.9668 before the installation of SVC and TCSC, but it became 1.0018 and by installing SVC in this system, voltage profile of load buses at bus 10 increases significantly.

Table 1: Comparing loss index before and after devices in IEEE 24-bus system

\begin{tabular}{ccccl}
\hline Case & Without Facts & With SVC & With TCSC & With SVC and TSCS \\
\hline Location & -- & Bus 10 & Line 27 & Svc Bus 10 TCSC Line 27 \\
Size & -- & $225.69 \mathrm{Mvar}$ & 0.581 & $225.69 \mathrm{Mvar}$ \\
& & & & 0.581 \\
Losses & $225.68 \mathrm{Mva}$ & $218.786 \mathrm{Mva}$ & $208.865 \mathrm{Mva}$ & $201.765 \mathrm{Mvar}$ \\
\hline
\end{tabular}

After using the proposed GA method to find the best location and value for SVC and TCSC we find that the losses in the system decreased a lot and when looking at Table 1. We find that the losses became 201.765 Mva after installing TCSC and SVC after it was 225.68Mva without FACTS devices. In other words, this index was improved.

\section{CONCLUSION}

In order to study simulation, Genetic Algorithm is implemented on a sample bus of an IEEE 24-bus system with real coding and the obtained results are discussed along with corresponding diagrams and tables. Obtained results show that considering loss index and installing SVC in both systems, voltage profile of load buses increases significantly. Furthermore, considering loss index and installing a combination of SVC and TCSC in both systems, voltage profile of load buses increases. By installing a combination of SVC and TCSC, loss index becomes lower compared to when no such device is installed, SVC is installed, or TCSC is installed, which shows improvement of this index.

\section{REFERENCES}

[1] Dazahra MN, Elmariami F, Belfqih A, Boukherouaa J.( 2016) Optimal Location of SVC using Particle Swarm Optimization and Voltage Stability Indexes. International Journal of Electrical and Computer Engineering, 6(6):2581.

[2] Mirjalili S. (2016) Dragonfly algorithm: a new meta-heuristic optimization technique for solving single-objective, discrete, and multi-objective problems. Neural Computing and Applications, 27(4):1053-1073.

[3] Jordehi AR. (2016) Optimal allocation of FACTS devices for static security enhancement in power systems via imperialistic competitive algorithm (ICA). Applied Soft Computing, 48:317-328.

[4] Darabian M, Jalilvand A. (2017) A power control strategy to improve power system stability in the presence of wind farms using FACTS devices and predictive control. International Journal of Electrical Power \& Energy Systems, 85:50-66.

[5] Nwohu MN, Isah A, Usman AU, Sadiq AA. (2016) Optimal placement of Thyristor Controlled Series Compensator (TCSC) on Nigerian 330kV transmission grid to minimize real power losses. International Journal of Research studies in Electrical and Electronics Engineering, 2:18-26.

[6] Raj S, Bhattacharyya B.( 2018) Optimal placement of TCSC and SVC for reactive power planning using Whale optimization algorithm. Swarm and Evolutionary Computation, 
40:131-143.

[7] Yu M, Xie H, Song W, WANG H, HE J, XIN H. ( 2017) Impact of SVC control mode on voltage abnormal oscillation in wind power influx area. Autom Electr Power Syst, 41(1):7378 .

[8] Sen D, Ghatak SR, Acharjee P. (2019) Optimal allocation of static VAR compensator by a hybrid algorithm. Energy Systems, 10(3):677-719.

[9] Zare K, Hagh MT, Morsali J.( 2015) Effective oscillation damping of an interconnected multi-source power system with automatic generation control and TCSC. International Journal of Electrical Power \& Energy Systems, 65:220-230.

[10] Sahoo DK, Sahu RK, Sekhar GTC, Panda S. (2018) A novel modified differential evolution algorithm optimized fuzzy proportional integral derivative controller for load frequency control with thyristor controlled series compensator. Journal of Electrical Systems and Information Technology, 5(3):944-963.

[11] Sodeifian G, Sajadian SA, Ardestani NS. (2017) Experimental optimization and mathematical modeling of the supercritical fluid extraction of essential oil from Eryngium billardieri: application of simulated annealing (SA) algorithm. The Journal of Supercritical Fluids, 127:146-157.

[12] Martí R, Martínez-Gavara A, Sánchez-Oro J, Duarte A. (2018) Tabu search for the dynamic Bipartite Drawing Problem. Computers \& Operations Research, 91:1-12.

[13] Babu TS, Rajasekar N, Sangeetha K. (2015) Modified particle swarm optimization technique based maximum power point tracking for uniform and under partial shading condition. Applied Soft Computing, 34:613-624.

[14] Gubin A V, Borzunov DY, Marchenkova LO, Malkova TA, Smirnova IL. (2016) Contribution of GA Ilizarov to bone reconstruction: historical achievements and state of the art. Strategies in Trauma and Limb Reconstruction, 11(3):145-152.

[15] Kia M, Nazar MS, Sepasian MS, Heidari A, Siano P.( 2017) Optimal day ahead scheduling of combined heat and power units with electrical and thermal storage considering security constraint of power system. Energy, 120:241-252. 